J. Clin. Chem. Clin. Biochem.

Vol. 27, 1989, pp. $423-427$

(C) 1989 Walter de Gruyter \& Co. Berlin - New York

\title{
Circulating Levels of Calcitonin Gene-Related Peptide in Patients with Medullary Thyroid Carcinoma
}

\author{
By Shouei Kim, Shigeto Morimoto
}

Department of Geriatric Medicine, Osaka University Medical School, Fukushima-ku, Osaka 553, Japan

\section{Yuriko Kawai}

Department of Neuroanatomy, Osaka University Medical School, Fukushima-ku, Osaka 553, Japan

Eio Koh, Toshio Onishi and Toshio Ogihara

Department of Geriatric Medicine, Osaka University Medical School, Fukushima-ku, Osaka 553, Japan

(Received November 21, 1988/April 3, 1989)

Summary: Calcitonin gene-related peptide, originally found in rat medullary thyroid carcinoma cells, was measured by radioimmunoassay in plasma samples with added aprotinin from 17 normal volunteers and 21 patients with medullary thyroid carcinoma. The concentrations were below $75 \mathrm{pmol} / \mathrm{l}$ in all 17 normal subjects with a mean of $33 \pm 19 \mathrm{pmol} / 1$ plasma. In the patients, the plasma calcitonin gene-related peptide concentrations ranged from below $5 \mathrm{pmol} / 1$ to $236 \mathrm{pmol} / \mathrm{l}$, although the mean $(36 \pm 48 \mathrm{pmol} / \mathrm{l})$ was not significantly different from the mean normal level. Increase in the plasma calcitonin gene-related peptide level was observed in 2 of 5 patients in response to infusion of $4.3 \mathrm{mg} / \mathrm{kg}$ of calcium for 10 minutes and in 3 of 5 patients in response to infusion of $4 \mu \mathrm{g} / \mathrm{kg}$ of tetragastrin for 5 minutes. These observations suggest that measurement of calcitonin gene-related peptide level may be helpful in determination of diseases in which the level of calcitonin is of less diagnostic value.

\section{Introduction}

With the isolation of a cell strain with low calcitonin synthesizing capacity by repetitive metagenetic culture of rat medullary thyroid carcinoma cells, it became possible to study the mode of expression of the calcitonin gene; this cell strain was shown to synthesize calcitonin gene-related peptide, which differs from calcitonin (1). It is now generally accepted that two kinds of peptides are coded by the calcitonin gene, and that mRNA transcribed from the calcitonin gene undergoes two alternative types of splicing to become calcitonin mRNA (which encodes calcitonin) or calcitonin gene-related peptide mRNA (which encodes calcitonin gene-related peptide) $(2,3)$. This splicing mechanism has been reported to be organ-specific: calcitonin is mainly synthesized in the thyroid, and calcitonin gene-related peptide mainly in the central nervous system $(3,4)$.

Unlike many other known peptides, calcitonin generelated peptide was synthesized artificially by a procedure established on the basis of molecular analysis of the calcitonin gene, and it was then detected in vivo by an immunohistological method. Calcitonin gene-related peptide reportedly exerts various physiological actions, such as suppression of appetite (5), inhibition of secretion of gastric acid or gastric juice $(6,7)$, vasodilatation (8), inhibition of gallbladder contractility (9), and stimulation of secretions of renin (10) and atrial natriuretic peptide (11). Immunohistological studies have shown that calcitonin gene- 
related peptide is widely distributed in the central nervous system $(4,12,13)$ and in peripheral ganglia (14), suggesting that it may be an neurotransmitter. However, the physiological role(s) of this peptide in humans is unknown. We established a radioimmunoassay for the measurement of human calcitonin gene-related peptide and determined the plasma concentrations of this peptide in healthy subjects and patients with medullary thyroid carcinoma.

\section{Materials and Methods}

\section{Materials}

Human calcitonin gene-related peptide $(1-37)$, rat calcitonin gene-related peptide $(1-37)$, human calcitonin $(1-32)$, and human parathyrin $(1-84)$ were purchased from the Peptide Institute (Osaka, Japan). Human ${ }^{125}$ I-labelled calcitonin gene-related peptide $\left(74 \times 10^{15} \mathrm{~Bq} / \mathrm{mol}\right)$ was obtained from Amersham Japan, Ltd. (Tokyo, Japan). Anti-calcitonin gene-related peptide antibody (a gift from Prof. I. MacIntyre, Royal Postgraduate Medical School, London, England), was produced by sensitizing rabbits with rat $\mathrm{Tyr}^{\circ}$-calcitonin gene related peptide(28 - 37) coupled with egg albumin (15). Anti-rabbit-globulin goat serum :and normal rabbit serum were from Eiken Immunochemical Co. (Tokyo, Japan). All other materials were from Wako Pure Chemical Co. (Osaka, Japan).

\section{Subjects}

The subjects examined were 17 healthy volunteers (mean age $\pm \mathrm{SD}, 31 \pm 9$ years: range, $20-49$ years; 4 males and 13 females) and 21 patients with medullary thyroid carcinoma (41 \pm 13 years; $14-63$ years; 4 males and 17 females). The diagnosis of medullary thyroid carcinoma was established by the presence of hypercalcitoninaemia either in the basal state or in response to calcium infusion in the test described below, and was confirmed surgically in all cases. Blood samples were obtained early in the morning after an overnight fast using syringes containing $4 \mathrm{mmol} / \mathrm{l} \mathrm{EDTA} \cdot 2 \mathrm{Na}$ and $0.5 \times 10^{6} \mathrm{KIU} / \mathrm{l}$ of aprotinin. Samples were cooled on ice and promptly centrifuged, and the plasma was stored at $-50^{\circ} \mathrm{C}$ until used. Five of the medullary thyroid carcinoma patients ( 2 males, 3 females) received a provocation test with $4.3 \mathrm{mg} / \mathrm{kg}$ (iv, 10 minutes) of calcium ( $20 \mathrm{~g} / \mathrm{l}$ calcium chloride) or $4 \mu \mathrm{g} / \mathrm{kg}$ (iv, 5 minutes) of tetragastrin, and blood samples were taken before and after the test.

Radioimmunoassay of calcitonin gene-related peptide

Control plasma was prepared as follows: Normal human peripheral blood was collected in assay tubes containing $4 \mathrm{mmol} / \mathrm{l}$ EDTA $\cdot 2 \mathrm{Na}$ and $0.5 \times 10^{6} \mathrm{KIU} / 1$ of aprotinin, and plasma was separated by centrifugation for 10 minutes at $3000 \mathrm{~g}$. This normal plasma was mixed with $50 \mathrm{~g} / \mathrm{kg}$ charcoal (Norite A) with stirring for 1 hour and centrifuged at $10000 \mathrm{~g}$ for 30 minutes. The resulting supernatant was filtered twice through a millipore filter (type HA, pore size $0.45 \mu \mathrm{m}$; Millipore Corporation, Massachusetts). The radioactivity of human ${ }^{125} \mathrm{I}$-labelled calcitonin gene-related peptide remaining after this procedure was less than $1 \%$. For assay of human calcitonin generelated peptide the reaction mixture, total volume $500 \mu \mathrm{l}$, contained $100 \mu \mathrm{l}$ of control plasma (containing standard human calcitonin gene-related peptide) or test plasma, about 20000 counts per minute of human ${ }^{125}$ I-labelled calcitonin gene-related peptide, anti-calcitonin gene-related peptide serum diluted to a final concentration of $1: 18000$, an appropriate amount of aprotinin to give a final concentration of $2 \times 10^{6} \mathrm{KIU} / \mathrm{l}$, and buffer. The buffer employed was $100 \mathrm{mmol} / \mathrm{l}$ sodium phosphate buffer containing $150 \mathrm{mmol} / 1 \mathrm{NaCl}, 1.2 \mathrm{mmol} / \mathrm{l}$ EDTA, and 15 $\mathrm{mmol} / 1 \mathrm{NaN}_{3}$ (pH 7.4). After incubation of the mixture of $4^{\circ} \mathrm{C}$ for 48 hours, bound and free human calcitonin gene-related peptide were separated by the double antibody method, with the second antibody and normal rabbit serum, with incubation at $4^{\circ} \mathrm{C}$ for 24 hours. Some plasma samples were examined in an assay system without aprotinin.

Stability of human ${ }^{125}$ I-labelled calcitonin gene-related peptide in plasma samples

The stability of human ${ }^{125}$ I-labelled calcitonin gene-related peptide in plasma was studied as follows. Plasma samples from normal subjects after overnight fasting were collected in assay tubes containing $4 \mathrm{mmol} / \mathrm{l}$ EDTA $\cdot 2 \mathrm{Na}$ alone. Samples were incubated as described above and also for 96 hours instead of 48 hours. After incubation, the mixtures were subjected to gel chromatography on a Bio Gel P-2 column $(1.6 \times 50 \mathrm{~cm})$. Materials were eluted with the assay buffer, and their elution profiles were compared.

\section{Radioimmunoassay for calcitónin}

Plasma calcitonin was determined with a commercial radioimmunoassay kit (Daiichi Radioisotope Laboratories, Ltd., Tokyo, Japan) by the procedure described previously (16).

\section{Statistical analysis}

Statistical analyses were performed by Student's $t$ test. Concentrations of plasma calcitonin gene-related peptide of less than the detection limit ( 5 pmol/l) were taken as 5 pmol/1.

\section{Results}

Stability of human ${ }^{125}$ I-labelled calcitonin gene-related peptide

Figure 1 shows the gel-filtration profiles of human ${ }^{125}$ I-labelled calcitonin gene-related peptide $(1-37)$ incubated with plasma samples with and without 1000 $\mathrm{KIU} /$ tube aprotinin. Most of the radioactivity in samples incubated for 48 hours without aprotinin was eluted in the low molecular region, indicating that much of the tracer was degraded during the incubation. This degradation progressed during further incubation for up to 96 hours, but was markedly inhibited by $1000 \mathrm{KIU} /$ tube $\left(2 \times 10^{6} \mathrm{KIU} / \mathrm{l}\right)$ of aprotinine. Therefore, this concentration of aprotinin was added in all subsequent assays.

\section{Radioimmunoassay for human calcitonin gene-related peptide}

Figure 2 shows the standard curve for calcitonin generelated peptide. The sensitivity of the assay, defined as the concentration of human calcitonin gene-related peptide at a point on the standard curve 2 standard deviations from the maximum binding $\left(B_{o}\right)$, was 


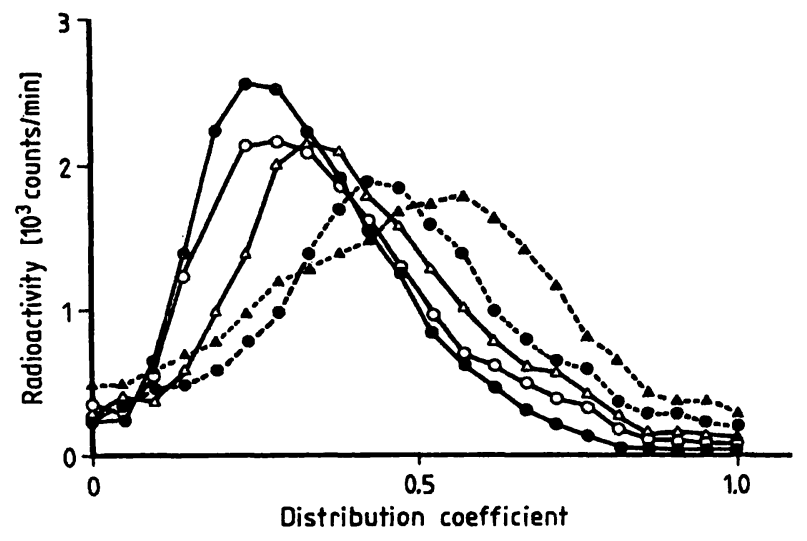

Fig. 1. Degradation of human ${ }^{125}$ I-labelled calcitonin gene-related peptide in normal plasma. Plasma was incubated with and without $1000 \mathrm{KIU} /$ tube of aprotinin at $4{ }^{\circ} \mathrm{C}$ for 48 hours or 96 hours. It was then analysed by gelchromatography on a Bio Bel P-2 $1.6 \times 50 \mathrm{~cm}$ column developed with $100 \mathrm{mmol} / \mathrm{l}$ sodium phosphate buffer, pH 7.4, containing $150 \mathrm{mmol} / 1 \mathrm{NaCl}, 1.2$ EDTA and $15 \mathrm{mmol} / 1 \mathrm{NaN}_{3}$. Symbols: - - $\bullet$, control; O-O, with aprotinin for 48 hours; $\Delta-\Delta$, with aprotinin for 96 hours; $0---\odot$, without aprotinin for 48 hours; $\Delta-\Delta$, without aprotinin for 96 hours.

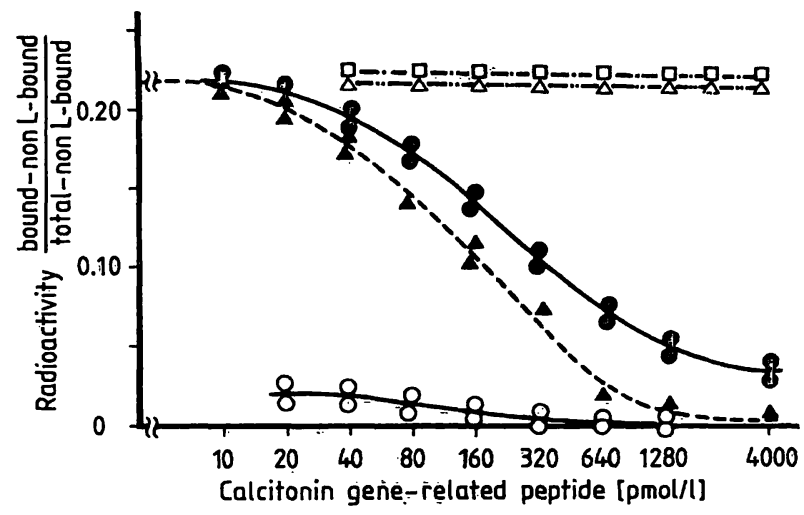

Fig. 2. Standard curve of human calcitonin gene-related peptide with (๑) and without (0) $1000 \mathrm{KIU} /$ tube of aprotinin, and cross-reactivities of rat calcitonin gene-related peptide $(\Delta)$, human-calcitonin $(1-32)(\Delta)$ and human parathyrin $(1-84)(\underline{0})$ with antiserum.

$5 \mathrm{pmol} / \mathrm{l}$. The curve was not satisfactory in the absence of aprotinin. The intra and interassay coefficients of variation were $6.0 \%$ and $8.0 \%$, respectively, and the recovery was $104.9 \pm 16.7 \%$. When plasma samples containing three different concentrations of human calcitonin gene-related peptide were diluted sequentially, the resultant dilution curve of each showed good linearity. The cross-reactivity of anti-rat Tyr $^{0}-$ calcitonin gene-related peptide $(28$ - 37) rabbit-serum with human calcitonin gene-related peptide $(1-37)$ was $56 \%$ of its reactivity with rat calcitonin generelated peptide $(1-37)$. However, no cross-reactivity with either human calcitonin(1-32) or human parathyrin(1-84) was detected (fig. 2).
Plasma calcitonin gene-related peptide levels in normal subjects and patients with medullary thyroid carcinoma

As shown in figure 3 , the basal plasma concentrations of calcitonin gene-related peptide in normal subjects ranged from below the detection limit $(<5 \mathrm{pmol} / \mathrm{l})$ to $75 \mathrm{pmol} / \mathrm{l}$, with a mean of $33 \pm 19 \mathrm{pmol} / \mathrm{l}$. The basal calcitonin gene-related peptide concentrations in medullary thyroid carcinoma patients ranged from below the detection limit to $236 \mathrm{pmol} / \mathrm{l}$, although the mean level in this group $(35 \pm 48 \mathrm{pmol} / \mathrm{l})$ did not differ significantly from that in the normal group. Figure 4 shows the relation between the plasma calcitonin and calcitonin gene-related peptide levels in the 21 patients with medullary thyroid carcinoma. There was a significant correlation $(r=0.48$, $\mathrm{p}<0.05)$ between the two parameters after their logarithmic transformation.

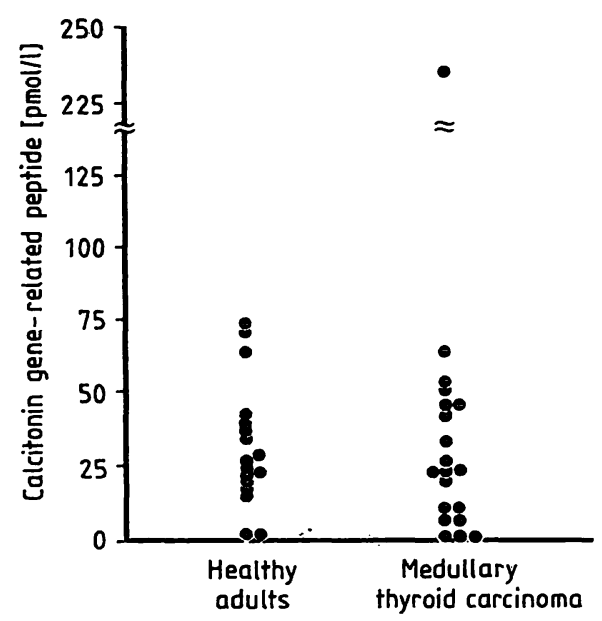

Fig. 3. Plasma calcitonin gene-related peptide levels in 17 normal subjects and 21 patients with medullary thyroid carcinoma.

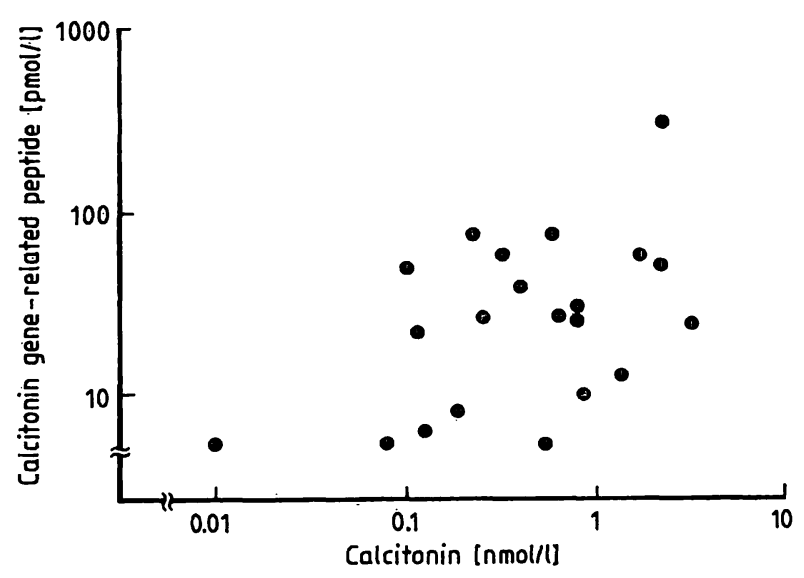

Fig. 4. Correlation of plasma concentations of calcitonin and calcitonin gene-related peptide in 21 patients with medullary thyroid carcinoma. Linear regression of logarithmically transformed data on individual plasma concentrations of calcitonin gene-related peptide and calcitonin showed a significant correlation $(r=0.48$, $\mathrm{p}<0.05)$. 
Table 1 shows the responses of plasma calcitonin and calcitonin gene-related peptide to infusion of calcium and tetragastrin in five patients with medullary thyroid carcinoma. The plasma calcitonin levels in all five patients increased significantly in response to these provocation tests, but increases in the plasma calcitonin gene-related peptide levels were observed in only 2 patients in the former test and 3 patients in the latter test.

Tab. 1. Plasma concentrations of human calcitonin and calcitonin gene-related peptide in response to intravenous administration of $4.3 \mathrm{mg} / \mathrm{kg}$ calcium and of $4 \mu \mathrm{g} / \mathrm{kg}$ of tetragastrin in 5 patients with medullary thyroid carcinoma.

\begin{tabular}{|c|c|c|c|c|}
\hline \multirow[t]{2}{*}{ Patient } & \multicolumn{2}{|c|}{ Plasma calcitonin (pmol/l) } & \multicolumn{2}{|c|}{$\begin{array}{l}\text { Plasma calcitonin gene- } \\
\text { related peptide (pmol/l) }\end{array}$} \\
\hline & Basal & $10 \mathrm{~min}$ & Basal & $10 \mathrm{~min}$ \\
\hline \multicolumn{5}{|c|}{ Calcium infusion test } \\
\hline $\begin{array}{l}1 \\
2 \\
3 \\
4 \\
5\end{array}$ & $\begin{array}{r}539 \\
1878 \\
2723 \\
208 \\
605\end{array}$ & $\begin{array}{r}827 \\
4282 \\
32846 \\
388 \\
16322\end{array}$ & $\begin{array}{l}64 \\
51 \\
45 \\
23 \\
24\end{array}$ & $\begin{array}{r}78 \\
30 \\
60 \\
<5 \\
18\end{array}$ \\
\hline \multicolumn{5}{|c|}{ Gastrin infusion test } \\
\hline $\begin{array}{l}1 \\
2 \\
3 \\
4 \\
5\end{array}$ & $\begin{array}{r}556 \\
2989 \\
14672 \\
216 \\
3183\end{array}$ & $\begin{array}{r}735 \\
13416 \\
32562 \\
315 \\
7776\end{array}$ & $\begin{array}{l}54 \\
34 \\
41 \\
12 \\
26\end{array}$ & $\begin{array}{l}52 \\
66 \\
52 \\
23 \\
16\end{array}$ \\
\hline
\end{tabular}

\section{Discussion}

The anti-rat-Tyr ${ }^{0}$ calcitonin gene-related peptide $(28=$ 37) antibody used in this study was reported to crossreact with rat calcitonin gene-related peptide and human calcitonin gene-related peptide, but not with many other peptide hormones such as human parathyrin, adrenocorticotropin, substance $P$, somatostatin and oxytocin (13). In our experiment, the crossreactivity of human calcitonin gene-related peptide with this antibody was $56 \%$ of that of rat calcitonin gene-related peptide. Our assay system seems to be suitable for clinical use because a satisfactory standard curve was obtained and good reproducibility of recovery was observed in dilution experiments.

Furthermore, the present study demonstrated that human ${ }^{125}$ I-labelled calcitonin gene-related peptide was degraded appreciably in the plasma, and that this degradation was inhibited by aprotinin, an inhibitor of proteolytic enzymes. Kraenzlin et al. reported that calcitonin gene-related peptide was rapidly degraded in vivo, and that its half life in the circulation was less than 30 minutes (17). These results suggest that plasma should be promptly separated and stored in an assay tube containing aprotinin, and that aprotinin should also be added before assays to prevent possible degradation of calcitonin gene-related peptide during incubation.

Recently, a method for measuring human calcitonin gene-related peptide by radioimmunoassay was reported by Zaidi et al. (18). In their assay system, the detection limit was $5 \mathrm{pmol} / \mathrm{l}$, and the cross-reactivity of human calcitonin gene-related peptide with the antibody was $60 \%$ of that of rat calcitonin generelated peptide. They also used aprotinin for preventing degradation of the peptide. Thus our assay system was comparable with theirs.

By our assay, the mean circulating concentration of calcitonin gene-related peptide in normal subjects was $33 \pm 19 \mathrm{pmol} / \mathrm{l}$, which was similar to the value reported by Girgis et al. (19).

Calcitonin gene-related peptide was first discovered in a molecular biological study of rat medullary thyroid carcinoma, and its level is thought to be elevated in patients with medullary thyroid carcinoma: in fact there are some reports of high levels of calcitonin gene-related peptide in these patients. An early report revealed rather high levels of circulating calcitonin gene-related peptide in patients with medullary thyroid carcinoma, but did not give details of the assay systems, including whether aprotinin was used to prevent degradation of the tracer in the assay system (15). Mason et al. measured circulating calcitonin gene-related peptide after extraction of plasma by acid ethanol, and detected high levels of calcitonin generelated peptide of $14-4866 \mathrm{pmol} / \mathrm{l}$ in 19 of 21 patients with medullary thyroid carcinoma, but plasma concentrations of below the detection limit $(10 \mathrm{pmol} / \mathrm{l})$ in the other two patients (20). They also observed increases in the circulating level of calcitonin generelated peptide in response to calcium and/or gastrin infusion in 6 patients (20). Schifter et al. also detected high basal levels of calcitonin gene-related peptide in 26 of 35 patients with medullary thyroid carcinoma, using a radioimmunoassay system with aprotinin. They observed significantly higher circulating levels of calcitonin than those of calcitonin gene-related peptide in these patients, but they also observed that the ratio of the two peptides varied from patient to patient and that only a small number of cells in tumours were stained by anti-calcitonin gèné-related peptide antibody (21). However, in our study, although the basal level of calcitonin gene-related peptide was high in one medullary thyroid carcinoma patient, the mean level in medullary thyroid carcinoma patients was not significantly different from that of normal controls. Moreover, changes in calci- 
tonin gene-related peptide levels after provocation with calcium or gastrin, which is known to stimulate calcitonin in man, differed in different individuals and were only modest in our study, although Mason et al. observed rather high responses of circulating calcitonin gene-related peptide in most of their patients with medullary thyroid carcinoma in these provocation tests.

The reason for the differences in the mean basal levels of calcitonin gene-related peptide and in its responses in provocation tests in our study and the studies of Mason et al. and Schifter et al. is unknown. A possible explanation is that the patients examined were in different stages of disease. Our patients may have been in a rather earlier stage of disease, as their circulating calcitonin levels ranges from $10 \mathrm{pmol} / \mathrm{l}$ to $3.3 \mathrm{nmol} / 1$ whereas those of most of the patients of Mason et al. and Schifter et al. were more than our highest level, and ranged up to more than $100 \mathrm{nmol} / \mathrm{l}$. The medullary thyroid carcinoma patients reported by Mason et al. and Schifter et al. included those with the much higher levels of circulating calcitonin than those in our study. But a few of their patients had calcitonin levels that were about the same as those in our study, and these patients had similar plasma cal- citonin gene-related peptide levels to those of our patients. Schifter et al. reported that calcitonin generelated peptide values increased rapidly in the terminal phase of this disease, and Mason et al. also stated that in their study the two patients with the highest plasma calcitonin gene-related peptide levels had particularly aggressive tumours.

It is interesting that the plasma calcitonin and calcitonin gene-related peptide levels in our medullary thyroid carcinoma patients in the early stage of the disease showed a significant positive correlation, since similar correlations were observed in the medullary thyroid patients studied by Mason et al. and Schifter et al.

More extensive studies are necessary on the secretion of calcitonin gene-related peptide and its behaviour in the circulation in both normal subjects and patients with medullary thyroid carcinoma.

\section{Acknowledgement}

This work was supported by grants from "the Research Program on Cell Calcium Signals in the Cardiovascular System" and the Ministry of Education, Science and Culture of Japan (Nos. 62570393 and 63570505). We are grateful to Miss Yoko Katsube and Yumiko Mayumi for secretarial assistance.

\section{References}

1. Rosenfeld, M. G., Amara, S. G., Roos, B. A., Ong, E. S. \& Evans, R. M. (1981) Nature 290, 63-65.

2. Amara, S. G., Jonas, V., Rosenfeld, M. G., Ong, E. S. \& Evans, R. M. (1982) Nature 298, 240-244.

3. Rosenfeld, M. G., Lin, C. R., Amara, S. G., Stolarsky, L., Roos, B. A., Ong, E. S. \& Evans, R. M. (1982) Proc. Natl. Acad. Sci. USA 79, 1717-1721.

4. Rosenfeld, M. G., Merunko, P. E., Rovier; J., Vale, W. W. \& Evans, R. M. (1983) Nature 304, 129-135.

5. Drahn, D. D., Gosnell, B. A., Levine, A. S. \& Morley, J. E. (1984) Peptides (Fayetteville) 5, $861-864$.

6. Hughes, J. J., Levine, A. S., Morley, J. E., Gosnell, B. A. \& Silivis, S. E. (1984) Peptides (Fayetteville) 5, 665-667.

7. Tache, Y., Pappas, Y., Lauffeñbürger, M., Goto, Y., Walsh, J. H. \& Debas, H. (1984) Gastroenterology 87, 344-349.

8. Brain, S. D., Williams, T. J., Tippins, J. R., Morris, H. A. \& MacIntyre, I. (1985) Nature 313, 54-56.

9. Hashimoto, T., Poston, G. J., Greeley, G. H. \& Thompson, J. C. (1988) Surgery 104, 419-423.

10. Kurtz, A., Muff, R., Born, W., Lundberg, J. M., Millberg, B. I., Gnadinger, M. P., Uehlinger, D. E., Weidmann, P., Hokfelt, T. \& Fischer, J. A. (1988) J. Clin. Invest. 82, $538-$ 543.

11. Yamămoto, A., Kimura, S., Hasui, K., Fujisawa, Y., Tamaki, T., Fukui, K., Iwao, H. \& Abe, Y. (1988) Biochem. Biophys. Res. Commun. 155, 1452-1458.
12. Gibson, S. J., Polak, J. M., Bloom, S. R., Sabate, I. M., Mulderry, P. K., Ghatei, M. A., McGregor, G. P., Morrison, J. F. B., Kelly, J. S., Evans, R. M. \& Rosenfeld, M. G. (1984) J. Neurosci. 2, 3101-3111.

13. Kawai, Y., Takami, K., Shiosaka, S., Emson, P. C., Hillyare, C. J., Girgis, S., MacIntyre, I. \& Tohyama, M. (1985) J. Neurosci. 15, 747-763.

14. Mason, R. T., Peterfreund, R. A., Sawhenko, P. E. M., Corrigan, A. Z., River, J. E. \& Vale, W. E. (1984) Nature $308,653-655$.

15. Morris, H. R., Panico, M., Etienne, T., Tippins, J., Girgis, S. I. \& MacIntyre, I. (1984) Nature 308, 746-748.

16. Okada, Y., Morimoto, S., Onishi, T., Tanaka, K., Tsuji, M., Kumahara, Y., Tsushima, S., Nakagawa, N., Ogawa, H. \& Sakakibara, S. (1978) Endocrinol. Jpn. 25, 617-620.

17. Kraenzlin, M. E., Ch'ng, J. L. C., Mulderry, P. K., Ghatei, M. A. \& Bloom, S. R. (1985) Regul. Pept. 10, 189-197.

18. Zaidi, M., Girgis, S. I. \& MacIntyre, I. (1988) Clin. Chem. $34,655-660$

19. Girgis, S. I., McDonald, D. W. R., Stevenson, J. C., Bevis, P. J. R., Lynch, C., Wimalawansa Self, C. H., Morris, H. R. \& Macintyre, I. (1985) Lancet $i i, 14-16$.

20. Mason, R. T., Shulkes, A., Zajac, J. D., Fletcher, A. E., Hardy, K. J. \& Martin, T. J. (1986) Clin. Endocrinol. 25, $675-685$.

21. Schifter, S., Williams, E. D., Craig, R. K. \& Hansen, H. H. (1986) Clin. Endocrinol. 25, 703-710.

Shigeto Morimoto, M.D.

Department of Geriatric Medicine

Osaka University Medical School

1-1-50 Fukushima

Fukushima-ku

Osaka 553, Japan 



\section{Proteases of Retroviruses}

\section{Proceedings of the Colloquium C 52}

\section{4th International Congress of Biochemistry \\ Prague, Czechoslovakia · July 10-15, 1988}

\section{Editor Vladimir Kostka}

1989. $17 \mathrm{~cm} \times 24 \mathrm{~cm}$. XII, 206 pages. Numerous illustrations.

Hardcover. DM 198,-; approx. US \$ 100.00 ISBN 3110118203

The book "Proteases of Retroviruses" provides initial information in the rapidly developing field of examination of proteolytic enzymes involved in the life cycle of $\mathrm{HIV}$ and of the most important oncogenic retroviruses. It summarizes the advance of the knowledge of retroviral proteases achieved most recently in virology, molecular biology and enzymology. It will become and invaluable tool for researchers working in these fields as well as for those interested in the design of new antivirals.

\section{From the Contents}

Introduction - Characteristics of Viral Proteases · Retrovirus Gene Products and Their Processing - Biosynthesis and Biochemical Characteristics of Retroviral Proteases - Bacterial Expression, Processing and Characterization of Recombinant Retroviral Proteases - Mutational Analyses of Retroviral Proteases - Structure, Function and Evolution of Retroviral Proteases - Author Index · Abbreviations · Subject Index 